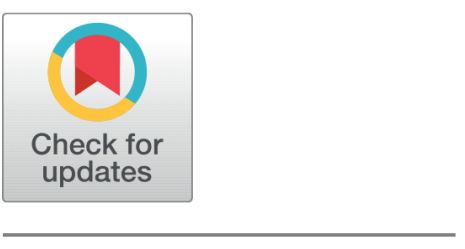

OPEN ACCESS

Received: 25-05-2020

Accepted: 19-06-2020

Published: 09-07-2020

Editor: Dr. Natarajan Gajendran

Citation: Prasad KN, N Jois S (2020) Effect of Pranic agriculture on vegetative growth characteristics of spinach (Spinacia oleracea L.). Indian Journal of Science and Technology 13(24): 2446-2451. https://doi.org/ 10.17485/IJST/v13i24.711

*Corresponding author. Srikanth $\mathrm{N}$ Jois

Research Head, World Pranic Healing Foundation India - Research Center, Mysuru, Karnataka, India.

Tel.: +91-821-2340673

research@pranichealing.co.in

Funding: World Pranic Healing Foundation India

Competing Interests: None

Copyright: $\Subset 2020$ Prasad, N Jois. This is an open access article distributed under the terms of the Creative Commons Attribution License, which permits unrestricted use, distribution, and reproduction in any medium, provided the original author and source are credited.

Published By Indian Society for Education and Environment (iSee)

\section{Effect of Pranic agriculture on vegetative growth characteristics of spinach (Spinacia oleracea L.)}

\author{
K Nagendra Prasad ${ }^{1}$, Srikanth $\mathrm{N}$ Jois $^{2 *}$ \\ 1 World Pranic Healing Foundation India - Research Center, Mysuru, Karnataka, India \\ 2 Research Head, World Pranic Healing Foundation India - Research Center, Mysuru, \\ Karnataka, India. Tel.: +91-821-2340673
}

\section{Abstract}

Objective: The present study was aimed to understand the application of pranic agriculture (PA) on the vegetative growth of Spinach. Methods: Spinach seeds were divided into non-pranic and pranic and sown in agricultural plots and growth parameters were recorded on 14, 26, 32, and 40 days respectively. The data were analyzed using Independent t-test at the $5 \%(p<.05)$ level of significance Findings: Shoot length and the number of leaves of Pranic treated Spinach were found to be significantly $(p<.001)$ higher when compared with non-pranic samples. Also, stem diameter, root length, and leaf lengths were all higher in pranic treated Spinach. Conclusion: Pranic agriculture has the potential to enhance Spinach growth and thus could help farmers to overcome the agrarian crisis.

Keywords: Prana; Pranic healing agriculture; Root length; Sustainable agriculture practices; Sustainable farming

\section{Introduction}

In India, Agriculture is a base for the growth of the Indian economy. A sustained agriculture growth provides a sturdy base for the overall growth of the country ${ }^{(1)}$. The most tragic face of India's agrarian crisis is seen in the increasing number of farmers' suicides. Several factors are associated with farmers suicide like the green revolution, declining agricultural production, low profits, low income, increasing cultivation cost, failure of crops, lack of irrigation and so on ${ }^{(2)}$. Several traditional sustainable agriculture practices can help to alleviate these problems. Increasing agriculture productivity sustainably is also one of the important indicators in achieving United Nations Sustainable Developmental Goals Indicator 2.a.1 by $2030^{(3)}$. Among them, Agnihotra, ${ }^{(4)}$ Meditation, ${ }^{(5)}$ use of Pyramid, ${ }^{(6)}$ Acoustic Farming, ${ }^{(7)}$ and Pranic Agriculture ${ }^{(8,9)}$ can help in an increase in agriculture production, with high profits in a sustainable way.

Pranic Agriculture (PA) is one of the ancient agriculture techniques. It helps in obtaining a higher yield with no additional inputs. It works by applying prana to enhance plant growth. Prana is also called qi energy or vital energy and is essential to keep the body alive and healthy. There are three major sources of prana namely air prana obtained from the air, ground prana obtained from ground, and solar prana from sunlight. Plants obtain prana from air, soil, sunlight, and water. PA can be implemented in any 
agriculture field practicing conventional farming with no additional cost. Hence, the application of PA is not a substitute, rather complementary in nature. Anyone with knowledge of Pranic Healing can easily adopt PA. ${ }^{(10)}$ By practicing PA, increase in seed germination, seedling vigor and yield, ${ }^{(9,11)}$ enhanced plant growth and agriculture yield, ${ }^{(12)}$ enhanced shelf-life has been recently reported. ${ }^{(13)}$ However, the exact mechanism of how Pranic Agriculture works is still not clearly understood.

Spinach (Spinacia oleracea L.) is a green leafy vegetable native to Central and Western Asia. It is normally grown for its delicious tender green leaves. It is consumed fresh or stored in dehydrated form or canned ${ }^{(14)}$. It is low in calories and a good source of various vitamins like Vitamin A, vitamin C, vitamin E, vitamin B2, vitamin B6 and vitamin K. It is also an excellent source of magnesium, manganese, folate, betaine, iron, calcium, potassium, folic acid, copper, protein, phosphorus, zinc, niacin, selenium, and omega-3 fatty acids. Spinach is also a good source of antioxidants, carotenoids, chlorophyll, and phytochemicals. The world production of Spinach was 26 million tonnes in 2018. It grows well in sandy loam soil. In India, Spinach is grown in Uttar Pradesh, West Bengal, Rajasthan, Maharashtra, Haryana, Gujarat, and Punjab, while in South it is not popularly grown. Spinach has a very good market demand due to its superior nutrient content and taste ${ }^{(15)}$. Given the importance of Spinach, there is a need to enhance its productivity. Hence, PA technique was chosen to understand its effect on Spinach vegetative growth.

\section{Materials and Methods}

\subsection{Plant material}

Spinach (Spinacia oleracea L.) seeds were procured from a local market in Mysore. The seeds free from any deformity and disease were handpicked and used for this study. The seeds were divided into two groups. Seeds with pranic treatment were referred to as a pranic group, while the other group which did not receive any treatment was referred to as a non-pranic group. A controlled block design was used for this study.

\subsection{Experimental setup}

This study was conducted at a private agriculture farm in Mysore in the year April-May, 2017. Two experimental plots of $30 \mathrm{ft}$ $\times 25 \mathrm{ft}$ each in the farm was selected. It was named pranic and non-pranic. The soil of pranic group received pranic treatment, while the soil of non-pranic group did not receive any treatment.

\subsection{Pranic treatment}

Spinach seeds and soils separated as the pranic group was given pranic treatment. The contaminated energies from the soil and seeds of the pranic group were removed. Later the soil and seeds of the pranic groups were energized with fresh prana. Each treatment lasted for five minutes and it was done three times per week.

\subsection{Growing Conditions}

In the pranic group plot, pranic group seeds were sown and in the non-pranic group plot, non-pranic group seeds were sown. Seeds were sown in the soil at a depth of $1 \mathrm{~cm}$ and both the plots were watered thrice a week. The temperature ranged between 29 $35^{\circ} \mathrm{C}$ with a relative humidity of $72-80 \%$. The plants were harvested on days $14,26,32$, and 40 separately and growth parameters of individual plants of the pranic group and the non-pranic group were recorded.

\subsection{Growth characteristics of Spinach}

Plant length parameters such as shoot length, root length, leaf length were measured using the scale. Shoot diameter was measured using Vernier calipers. The number of fully opened leaves born on the main stem was counted manually.

\subsection{Statistical Analysis}

The data collected have been analysed and tabulated as a mean value \pm standard error (SE) of ten plants as replicates for each treatment. The analysis was performed using SPSS version 21 and the mean-variance of the data was analysed using Independent t-test at the $5 \%(\mathrm{p}<.05)$ level of significance. 


\section{Results \& Discussion}

The present work was conducted to investigate the effect of PA on Spinach growth and the results revealed a significant difference in growth as shown in Figure 1. To evaluate the PA effect on the shoot and root lengths, it was observed that PA treatment enhanced the Spinach growth. The shoot length recorded at the days 14, 26, 32, and 40 for non-pranic the group were 5.28 \pm .46 , $6.77 \pm .24,8.57 \pm .43,8.74 \pm .43 \mathrm{~cm}$ respectively. However, for the Pranic group, shoot lengths recorded for all the number of days given were significantly higher $(\mathrm{p}<.001)$ except the 14th-day observation when compared with control and it was found to be $6.61 \pm .26,11.19 \pm .67,16 \pm .99$ and $20.47 \pm 1.12 \mathrm{~cm}$ respectively ( Table 1 ). It was found that the Pranic group shoot length increase against the non-pranic group was ranging from $25-134 \%$. Wahocho ${ }^{(16)}$ reported a control plant height of $8.13 \mathrm{~cm}$, while Citak and Sonmez ${ }^{(17)}$ reported a control plant height of $9.8 \pm .74$ which is similar to our findings in the non-pranic group $(8.74 \pm .43 \mathrm{~cm})$. With the application of Nitrogen fertilizer at $70 \mathrm{~kg} /$ hectare, Wahocho ${ }^{(16)}$ reported a plant height of $20.4 \mathrm{~cm}$, while Citak and Sonmez ${ }^{(17)}$ reported a plant height of $19.6 \mathrm{~cm}$ with the application of mineral fertilizer. In our study, Pranic treated plant height was found to be $20.47 \pm 1.1 \mathrm{~cm}$ without the application of any fertilizers. Thus, using Pranic agriculture, chemical fertilizer application could be minimized. This will benefit the farmer in terms of environmental sustainability and also reduce the need to buy harmful fertilizers.

A similar trend was noted in stem diameter wherein the pranic group was higher $(2.4-3.6 \mathrm{~cm})$ when compared with the non-pranic group (1.8-2.2 cm). Hence, an increase in stem diameter ranging from 33-66\% is noticed in the pranic group when compared with the non-pranic group ( Table 2). Stem diameter in Spinach (control group) of $2.9 \mathrm{~cm}$ was reported by Islam ${ }^{(14)}$ which is in close agreement with our current findings in the non-pranic group $(2.20 \pm .2 \mathrm{~cm})$.

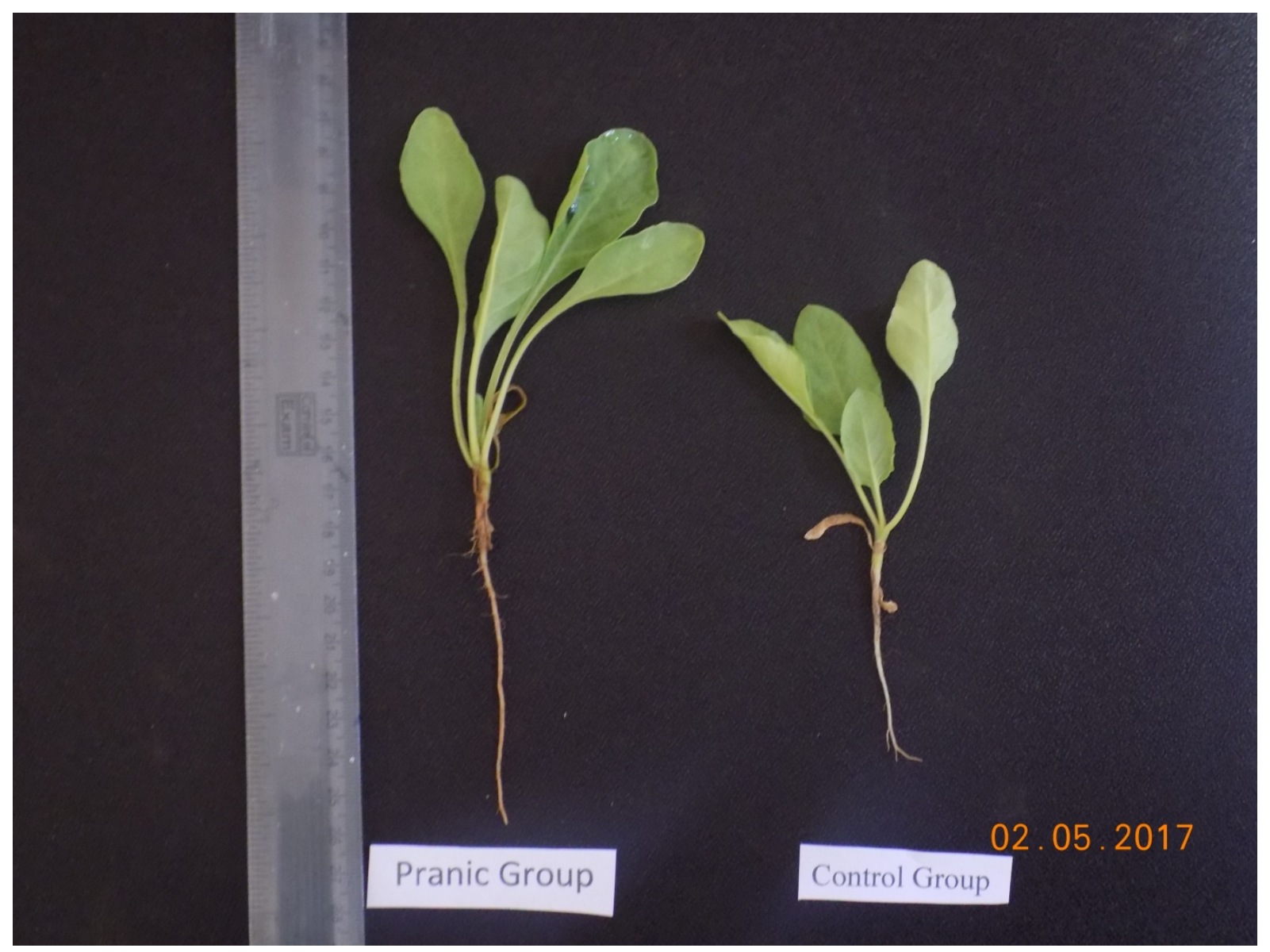

Fig 1. Growth characteristics of Pranic and Non-pranic Spinach plants 
Table 1. Comparison of shoot length $(\mathrm{cm})$ in Spinach plant at different number of days

\begin{tabular}{|c|c|c|c|c|c|c|}
\hline Growth Characteristic & Record of Observation & Non-Pranic & Pranic & Mean difference (\%) & Statistics & \\
\hline & & Mean \pm S.E & Mean \pm S.E & & t- Value & Sig \\
\hline \multirow{4}{*}{ Shoot length } & 14th day & $5.28 \pm .46$ & $6.61 \pm .26$ & 25.19 & -2.50 & .023 \\
\hline & 26th day & $6.70 \pm .24$ & $11.19 \pm .67$ & 67.01 & -6.23 & .000 \\
\hline & 32nd day & $8.57 \pm .43$ & $16.0 \pm .99$ & 86.70 & -6.87 & .000 \\
\hline & 40th day & $8.74 \pm .43$ & $20.47 \pm 1.1$ & 134.21 & -9.74 & .000 \\
\hline
\end{tabular}

Table 2. Comparison of shoot diameter $(\mathrm{cm})$ in Spinach plant at different number of days

\begin{tabular}{|c|c|c|c|c|c|c|}
\hline Growth Characteristic & Record of Observation & Non-Pranic & Pranic & Mean Difference (\%) & Statistics & \\
\hline & & Mean \pm S.E & Mean \pm S.E & & t- Value & Sig \\
\hline \multirow{3}{*}{ Shoot diameter } & 26th day & $1.80 \pm .18$ & $2.40 \pm .16$ & 33.33 & -2.06 & .054 \\
\hline & 32nd day & $1.90 \pm .13$ & $3.11 \pm .26$ & 63.68 & -4.62 & .000 \\
\hline & 40th day & $2.20 \pm .20$ & $3.66 \pm .23$ & 66.36 & -4.77 & .000 \\
\hline
\end{tabular}

The number of leaves/plants in the pranic group was more against the non-pranic group, but the results were not significant. On 14, 26, 32, and 40 days observed the number of leaves/ plants in the pranic group were $4.30 \pm .21,5.30 \pm .27,5.90 \pm .48$ and $5.90 \pm .50$ respectively. In the non-pranic group, it was $4.0 \pm .21,4.30 \pm .37,4.60 \pm .27$ and $5.20 \pm .36$ respectively ( Table 3 ). Our results are in close agreement with Ohashi-Kaneko ${ }^{(18)}$ wherein they have reported in Spinach the number of leaves/plants in control as 5.8. Citak \& Sonmez ${ }^{(17)}$ have reported in Spinach the number of leaves/plants in control as 5.7.

Table 3. Comparison of number of leaves in Spinach plant at different number of days

\begin{tabular}{|c|c|c|c|c|c|c|}
\hline Growth Characteristic & Record of Observation & Non-Pranic & Pranic & Mean Difference (\%) & Statistics & \\
\hline & & Mean \pm S.E & Mean \pm S.E & & t- Value & Sig \\
\hline \multirow{4}{*}{ Number of leaves } & $14^{\text {th }}$ day & $4.0 \pm .21$ & $4.30 \pm .21$ & 7.22 & -1.000 & .331 \\
\hline & $26^{\text {th }}$ day & $4.30 \pm .37$ & $5.30 \pm .27$ & 23.26 & -2.22 & .039 \\
\hline & $32^{\text {nd }}$ day & $4.60 \pm .27$ & $5.90 \pm .48$ & 28.26 & -2.36 & .030 \\
\hline & $40^{\text {th }}$ day & $5.20 \pm .36$ & $5.90 \pm .50$ & 13.46 & -1.13 & .273 \\
\hline
\end{tabular}

Leaf length of the pranic group was higher at any number of days given and the results were found to be significant $(\mathrm{P}<0.001)$ when compared with the non-pranic group. Leaf length ranged from $10.25 \pm .44 \mathrm{~cm}$ on the $26^{\text {th }}$ day of observation and increased to $14.09 \pm .62 \mathrm{~cm}$ on the $32^{\text {nd }}$ day. It was found to be $20.25 \pm 1.07 \mathrm{~cm}$ on the $40^{\text {th }}$ day. Control samples had leaf length of $6.40 \pm .25$, $7.36 \pm .25$ and $8.39 \pm .38 \mathrm{~cm}$ at $26^{\text {th }}, 32^{\text {nd, }}$ and $40^{\text {th }}$ day respectively ( Table 4). Thus, pranic group leaf length increased in the range of $60-141 \%$ when compared with the non-pranic group. Our results (non-pranic group) are in good agreement with Solangi et al. ${ }^{(19)}$ and Wohocho et al. ${ }^{(16)}$ reporting leaf length of $9.08 \mathrm{~cm}$ and $8.23 \mathrm{~cm}$ respectively from control Spinach plants.

Table 4. Comparison of leaf length $(\mathrm{cm})$ in Spinach plant at different number of days

\begin{tabular}{|c|c|c|c|c|c|c|}
\hline Growth Characteristic & Record of Observation & Non-Pranic & Pranic & Mean Difference (\%) & Statistics & \\
\hline & & Mean \pm S.E & Mean \pm S.E & & t-Value & Sig \\
\hline \multirow{3}{*}{ Leaf length } & $26^{\text {th }}$ day & $6.40 \pm .25$ & $10.25 \pm .44$ & 60.16 & -7.61 & .000 \\
\hline & $32^{\text {nd }}$ day & $7.36 \pm .25$ & $14.09 \pm .62$ & 91.44 & -10.04 & .000 \\
\hline & $40^{\text {th }}$ day & $8.39 \pm .38$ & $20.25 \pm 1.0$ & 141.35 & -10.44 & .000 \\
\hline
\end{tabular}

Root length in pranic treated Spinach was always higher when compared with the non-pranic group at any number of days given. At the $26^{\text {th }}$ day, root length of Spinach treated with pranic was found to be $7.85 \pm .58 \mathrm{~cm}$ while for non-pranic group it was $5.36 \pm .41 \mathrm{~cm}$ and the results were found to be not significant. An increase in root length of $46 \%$ was noticed in Pranic treated Spinach against the control ( Table 5). 
Table 5. Comparison of rootlength $(\mathrm{cm})$ in Spinach plant at different number of days

\begin{tabular}{|c|c|c|c|c|c|c|}
\hline Growth Characteristic & Record of Observation & Non-Pranic & Pranic & Mean Difference (\%) & Statistics & \\
\hline & & Mean \pm S.E & Mean \pm S.E & & t-Value & Sig \\
\hline \multirow{3}{*}{ Root length } & 26th day & $5.36 \pm .41$ & $7.85 \pm .58$ & 46.45 & -3.51 & .002 \\
\hline & 32nd day & $5.74 \pm .52$ & $5.66 \pm 45$ & -1.39 & 0.12 & .909 \\
\hline & 40th day & $6.55 \pm .66$ & $9.71 \pm .77$ & 48.24 & -3.11 & .006 \\
\hline
\end{tabular}

Earlier reports on pranic agriculture studies have noticed an increase in shoot length, stem diameter, root length, and the number of leaves. Prasad \& Jois ${ }^{(9)}$ reported an increase in shoot length by $30 \%$, root length by $40 \%$, and the number of leaves by $49 \%$ in pranic treated papaya against the control. In pranic treated drumstick, an increase in shoot length by $31 \%$, root length by $29 \%$ and the number of leaflets by $40 \%$ was observed ${ }^{(20)}$. Increase in plant height by $18.5 \%$, stem diameter by $12 \%$ and yield by $31 \%$ was reported in pranic treated tomatoes when compared with control ${ }^{(12)}$.

Healers have been shown to produce magnetic fields from their hands ${ }^{(21)}$. Magnetic fields have been shown to alter enzyme activity and will exert an effect by altering the $\mathrm{pH}$ of the enzyme ${ }^{(22)}$. Magnetic fields also help to decrease the soil $\mathrm{pH}$ and help in the release of organic acids which are more readily available for plants to enhance their growth. Magnetic treatment could influence desorption of phosphorous and potassium from the soil and thus increasing its availability to plants, resulting in improved plant growth and productivity ${ }^{(23)}$ Pranic treated Spinach plants had an increase in root length. Roots are responsible for the absorption of water and nutrients which are important resources affecting crop yields. Also, roots improve soil organic matter content and biological activity in the rhizosphere. The crop yield was significantly related to the total root length of the plants. Longer the root length, higher is the nutrition absorption by the plants ${ }^{(24)}$. Pranic group plants had more number of leaves and leaf length. This would facilitate to enhance photosynthesis activity of leaves and could lead to an increase in the productivity of plants ${ }^{(25)}$. The magnetic field also increases phytohormone production particularly Gibberellic acid (GA) and Indole-3-acetic-acid (IAA), which are known to enhance plant growth and leading to improved cell division. It should also be noted that the application of qi energy help in the increased rate of cellular growth and division. It also increases ATPase activity during seed germination of the dividing cells. These results in more energy supply to the cells during cell division, growth and differentiation probably resulting in enhanced growth of plants ${ }^{(26)}$. However, the exact mechanism of how Pranic Agriculture could increase plant growth needs to be investigated.

\section{Conclusion}

Pranic agriculture played a significant role in enhancing the vegetative growth of Spinach. It improved growth characteristics such as shoot length, root length, number of leaves, and leaf length. Overall, it can be concluded that PA treatment could help the farmers to enhance their productivity and overall yield.

\section{Acknowledgements}

Master Choa Kok Sui, the founder of Modern Pranic Healing for imparting the precise knowledge of Pranic Agriculture. World Pranic Healing Foundation, India for funding the study. Owner of Bhudevi Farm, Mysore for encouragement and support, Mr. Papanna NS for application of Pranic healing techniques and all those who contributed to the present study directly and indirectly.

\section{References}

1) Arjun KM. Indian agriculture-status, importance and role in Indian economy. International Journal of Agriculture and Food Science Technology. 2013;4(4):343-346.

2) Kumar A, Shinoj P and Joshi PK. Global economic crisis and indian agriculture: Impacts and perspectives. Indian Journal of Agricultural Economics. 2010;65:902-2016.

3) United Nations. The agriculture orientation index for government expenditures . 2018,. Available from: https://unstats.un.org/wiki/display/ SDGeHandbook/Indicator+2.a.1.

4) Abhang P and Pathade G. Agnihotra Technology in the Perspectives of Modern Science-A Review. Indian Journal of Traditional Knowledge. 2017;16(3):454-462.

5) Pandey ST, Verma O, Kewalanand, Pandey DS, Gill S, Patel JC et al. Yogic Farming through Brahma Kumaris Raja Yoga Meditation: An ancient technique for enchancing crop production. Asian Agri-History. 2015;19:105-122.

6) Rubik B. Interactions of pyramidal structures with energy and consciousness. The Journal of Natural and Social Philosophy. 2016;12(2):259-275.

7) Jiang SR and Huang J. Effects of music acoustic frequency on greenhouse vegetable. Journal of Zhejiang University of Science and Technology. 2012;24:287293. 
8) Krell R and Riebessel S. Pranic Agriculture - Comparative trials from Germany, India and Colombia . 2015,. Available from: https://www. pranichealingresearch.com/pranic-agriculture.

9) Prasad KN and Jois SN. Enhancement of Papaya (Carica papaya) Seedling Growth by Pranic Agriculture. AGRIVITA Journal of Agricultural Science. 2020;42(1):191-196. Available from: https://dx.doi.org/10.17503/agrivita.v42i1.2410.

10) Sui CK. The Ancient Science and Art of Pranic healing. 3rd ed. . India. Institute of Inner studies publishing foundation India Private Ltd. . 2015,.

11) Yathindra HA, Srikanth NJ, Prasad KN and Lancy D. Influence of pranic agriculture on germination, flowering and yield of European cucumber. Ecology, Environment and Conservation. 2017;23(3):545-538.

12) Jois SN, Roohie K, D'Souza L, Suma F, Devaki CS, Urooj A et al. Physico-Chemical Qualities of Tomato Fruits as Influenced By Pranic Treatment - an Ancient Technique for Enhanced Crop Development. Indian Journal of Science and Technology. 2017;9(46):1-5. Available from: https://dx.doi.org/10. $17485 /$ ijst/2016/v9i46/99733.

13) Jois SN, Prasad KN and Shalini NS. Enhancement of Shelf Life of Brinjal during storage using Pranic Agriculture protocol. Ecology, Environment and Conservation. 2019;25:287-290.

14) Islam MM, Karim AJMS, Jahiruddin M, Majid NM, Miah MG, Ahmed MM et al. Effects of organic manure and chemical fertilizers on crops in the radish-stem amaranth-Indian Spinach cropping pattern in homestead area. Australian journal of crop science. 2011;5(11):1370-1378.

15) Meena VK, Subramanian S, Dipti NV and Simta K. Introduction of palak (Spinacia oleracea L.) in Ernakulam district of Kerala through front line demonstration and on farm testing. Agriculture Science Digest. 2016;36(2):130-133.

16) Wahocho NA, Memon N, Kandhro MN, Miano TF, Talpur KH, Wahocho SA et al. Response of nitrogen on the growth and productivity of Spinach (Spinacia oleracea L.). Sindh University Research Journal-SURJ. 2016;48(2):305-308.

17) Citak $S$ and Sonmez S. Effects of conventional and organic fertilization on spinach (Spinacea oleracea L.) growth, yield, vitamin $C$ and nitrate concentration during two successive seasons. Scientia Horticulturae. 2010;126(4):415-420. Available from: https://dx.doi.org/10.1016/j.scienta.2010.08.010.

18) Ohashi-Kaneko K, Takase M, Kon N, Fujiwara K and Kurata K. Effect of Light Quality on Growth and Vegetable Quality in Leaf Lettuce, Spinach and Komatsuna. Environment Control in Biology. 2007;45(3):189-198. Available from: https://dx.doi.org/10.2525/ecb.45.189.

19) Solangi M, Suthar V, Wagan B, Siyal AG, Sarkc A and Soothar RK. Evaluate the Effect of Nitrogen and Phosphorus Fertilizer doses on Growth and yield of Spinach (Spinacia oleracea L.). Science International. 2016;28(1):379-383.

20) Prasad KN and Jois SN. Pranic Agriculture improves drumstick (Moringa olifera L.) germination and seedling growth. Ecology, Environment and Conservation. 2019;25:267-271.

21) Tiller WA. Towards explaining anomalously large body voltage surges on exceptional subjects, Part I: The electrostatic approximation. Journal of Scientific Exploration. 1995;9(3):331-331.

22) Bunnell TL. The Effect of "Healing with Intent" on Pepsin Enzyme Activity. Journal of Scientific Exploration. 1999;13(2):139-148.

23) Maheshwari BL and Grewal HS. Magnetic treatment of irrigation water: Its effects on vegetable crop yield and water productivity. Agricultural Water Management. 2009;96(8):1229-1236. Available from: https://dx.doi.org/10.1016/j.agwat.2009.03.016.

24) Fageria NK and Moreira A. The role of mineral nutrition on root growth of crop plants. In: Advances in agronomy. vol. 110. Academic Press . 2011,. p. 251-331.

25) Hirose T, Ackerly DD, Traw MB, Ramseier D and Bazzaz F. A. CO2 elevation, canopy photosynthesis, and optimal leaf area index. Ecology. 1997;78(8):2339-2350.

26) Bai F, Sun C, Liu Z, Shen J, Shen Y, Ge R et al. Seeds induced to germinate rapidly by mentally projected 'qi' energy are apparently genetically altered. The American journal of Chinese medicine. 2000;28(01):3-8. 